Jnl. Soc. Pol. (2022), 51, 4, 669-686 C The Author(s), 2021. Published by Cambridge University Press. This is an Open Access article, distributed under the terms of the Creative Commons Attribution licence (http:// creativecommons.org/licenses/by/4.0/), which permits unrestricted re-use, distribution, and reproduction in any medium, provided the original work is properly cited. doi:10.1017/S0047279421000441

\title{
Hybrid entitlement: Welfare recipients' perceptions of entitlement to social rights
}

\author{
Dr. EINAT LAVEE \\ Department of Human Services, Interdisciplinary Center for the Study of Poverty and Social \\ Exclusion, University of Haifa \\ email: elavee@univ.haifa.ac.il
}

\begin{abstract}
Recent decades have witnessed changes in welfare states, shaped by a neoliberal ideology that has reduced state responsibility for weakened populations and transformed definitions of citizenship from the universalist notion of social citizenship to the idea of market citizenship. Contemporary welfare policy is based on a disciplinary regime, which aims to produce selfdisciplined citizens who adhere to market rules as the most essential civic rules. Following this change in social contract between the state and its citizens, the notion of entitlement to social rights has been transformed into disentitlement to public support. However, economic independence via labour market participation is not always possible and many must rely on welfare support for material survival. This study aims to pinpoint the factors shaping welfare recipients' perceptions of entitlement. Drawing on 76 in-depth interviews with welfare recipients in Israel, we argue that people's perceptions of their entitlement to public support are disciplined by the "new" welfare regime of market citizenship, yet simultaneously influenced by "old" perceptions of universal citizenship rights. This kind of "hybrid entitlement" allows welfare recipients to resist exclusion and to avoid disconnection from work and welfare.
\end{abstract}

Keywords: citizenship; entitlement; neoliberalism; poverty; welfare state

\section{Introduction}

Entitlement to social rights is traditionally linked to the notion of social citizenship, based on Marshall's (1950) definition. According to Marshall, if a democratic order is to be fully maintained, every citizen must be entitled to 'the whole range, from the right to a modicum of economic welfare and security to the right to share to the full in the social heritage and to live the life of a civilized being according to the standards prevailing in society.' The modern welfare state model has been developed in keeping with this definition, and theoretically all citizens are seen as equally deserving of social rights. Entitlement, defined as the awareness of social rights, suggests a sense of deserving that can potentially lead to active claims of benefits and support.

In the past thirty years, many Western countries have been abandoning relatively generous welfare systems. They have adopted various configurations of welfare programs shaped by a neoliberal ideology that reduces state responsibility for 
the wellbeing of citizens (Fineman, 2004; Harvey, 2007; Liebenberg et al., 2015). These changes are commonly conceptualized as a move from social policies which protect from 'old social risks' to a 'new welfare' (Postan-Aizik and Strier, 2020). Although there are variations among countries, policy areas and institutions, these changes have largely been manifested in welfare restructuring. One major change entails minimizing state obligations with regard to a range of social rights of citizenship, including healthcare, education, housing and employment (Maman and Rosenhek, 2011). The result is "the great risk shift" (Hacker, 2019), whereby government and other collective safety nets shrink and responsibility for citizens' welfare and wellbeing is transferred to individuals.

In the context of changes in state responsibility for citizens and the withdrawal of social rights, awareness of changing policies may transform the sense of entitlement into disentitlement (Benjamin, 2016; Lavee and Benjamin, 2017). Strict welfare rules have changed the way people view their rights (Cox, 1998). The changing nature of entitlement has most impact in the lives of people who suffer economic distress - welfare recipients and others who cannot afford to privately purchase services previously provided by the state. It is clear that changes in the provision of social rights bring about changes in the perception of entitlement to social rights. Nevertheless, the literature has paid little attention to how people living in poverty and relying on state support adjust their moral considerations vis-à-vis these changes, and (most importantly) manage to avoid the disconnection often associated with negative feelings of exclusion. Recent works have provided meaningful evidence regarding poor people's reaction to oppressive policies and discourses (e.g. Feldman and Schram, 2019; Postan-Aizik and Strier, 2020). However, one crucial question remains open: what specific factors shape perceptions of entitlement among low-income people? The main analytical challenge is to explore relations between macro-level factors, such as ideology and social policy, and micro-level individual perceptions.

The concept of entitlement is often linked with citizenship. Citizenship is an inherently relational status, defined by the ways members of a polity are positioned vis-a-vis nonmembers, one another, the state and other major societal institutions (Crenson and Ginsberg, 2004). Under conditions of change in the welfare state, citizenship is reduced to the singular project of ensuring that one's needs are met through one's contribution to the market. Changing the social contract between the state and its citizens (Gilbert, 2009), welfare reform has transformed the universalist notion of social citizenship into the neoliberal idea of market citizenship (Schram et al., 2010). ${ }^{1}$ In this environment, state support is limited, its goal being to facilitate citizens' participation in the labour market (Galston, 2005). One central manifestation of this ideology is welfare-to-work programs, in which state support is given only to those who demonstrate an effort to participate in the labour market (Munger, 2002; Weigt, 2006). 
Schram and colleagues (Schram, 2008; Schram et al., 2010; Soss et al., 2011) explain that this welfare policy is based on a disciplinary regime, which aims to produce self-disciplined citizens who adhere to market rules, perceiving them as the most essential civic rules. Such a regime operates as a productive power, cultivating forms of self-discipline that lead actors to 'freely' adhere to normative standards of acceptable behavior (Dean, 2010). It pursues state purposes through the promotion of 'governing mentalities' - i.e. sets of assumptions, knowledge claims, appeals to authority, expertise, obligation and responsibility that structure the guiding rationale of public policy (Campbell, 2002).

We find the concept of a disciplinary regime and its relation to the changing nature of citizenship to be highly suitable for exploring relations between welfare state policy and individual perceptions of entitlement to social rights. Drawing on 76 in-depth interviews with welfare recipients in Israel, we argue that people's perceptions of state responsibility for the provision of social rights are disciplined by the 'new' welfare regime of market citizenship, yet simultaneously influenced by "old" perceptions of universal citizenship rights, creating a 'hybrid entitlement.'

Our contribution to social policy literature is twofold. First, our study explores the ramifications of welfare reform on recipients' labour market participation. This field has been characterised by studies that focus on the implications of the strict, market-centered policy on the maneuvering of welfare recipients within the labour market. This prism often presents former welfare recipients as passive 'containers' of the disciplining regime. A qualitative analysis focusing on this population's perceptions of state responsibility in this environment can capture the process-related features that constitute understanding of the demand to participate in the labour market in ways that actively diverge from the original purpose of the disciplinary regime.

Second, the article contributes to the debate on the changing nature of citizenship under the contemporary social contract (Gilbert, 2009). By focusing on perceptions of entitlement, we provide new insights into the ways in which people living in poverty overcome negative feelings of exclusion, perceive themselves as moral citizens and thereby succeed in avoiding further disconnection from both work and welfare.

\section{Theoretical background}

\section{Citizenship and perceptions of entitlement}

By definition, citizenship is both exclusionary and inclusionary. On the one hand, it is based on the principle of universality; on the other hand, the process of determining who does and does not deserve full rights of citizenship is in itself an exclusionary mechanism (Arnot and Dillabough, 2000). ${ }^{2}$ 
According to Lister (2004), class is a main exclusionary mechanism. She argues that a state of poverty necessarily leads to second-class citizenship (2004: 165), defined as processes of exclusion from participation in mainstream society and its social, economic, political, civic and cultural spheres. Similar to Lister's linkage between poverty and exclusion, a vast body of literature describes the exclusionary experience of life in poverty (e.g. Krumer-Nevo, 2002; Lavee, 2017; Strier, 2005). Nonetheless, it is possible that exclusionary experiences vary among those who live in poverty. Linking exclusion and entitlement to social rights might offer a new perspective with which to address this issue.

More than a result of life in poverty and exclusion from various forms of social life, excluded citizenship is a state of rupture between basic universal rights (e.g. carrying one's state's passport) and rights specific to one's state redistributive system (e.g. housing) (Lavee and Benjamin, 2017). Namely, despite a formal belonging, for those who are excluded and isolated, citizenship status is insufficient to entitle them to economic and social rights. As a result, their social exclusion, isolation and non-participation is reinforced (Pinson, 2008).

Given the relation between entitlement and citizenship, the literature usually links disentitlement of the poor to social rights based on moral or behavioral judgments, with perceptions of excluded citizenship (Benjamin, 2016; Lister, 2004). In keeping with this logic, a sense of entitlement might lead to perceptions of inclusion and full citizenship. To untangle this equation, we first need to understand who it is that is worthy and entitled.

\section{Disciplinary regime and entitlement to state support}

During the last three decades, most Western countries have experienced massive changes in social policies (Postan-Aizik and Strier, 2020). A change common to all, although in different degrees, is in marketization processes and related policies (Nieuwenhuis and Maldonado, 2018). In this context, welfare state reforms, which draw on a neoliberal ideology, have fundamentally changed the notion of social rights and citizenship in many industrialized nations (Cox, 1998).

As states have been restructured to operate according to market rationalities, citizenship too has shifted toward an economic register of identity and practice. The status of democratic citizens, positioned as decision-makers who act collectively to gain preferred policy outcomes, has been eroded and partly displaced by the individualist market roles of consumer, worker and paying customer (Crenson and Ginsberg, 2004). The long-standing acceptance of welfare as a social right has been replaced by an emphasis on recipients' social responsibilities (Gilbert, 2009).

Emphasizing the primacy of the market, the basic neoliberal principle states that citizenship is achieved through work commitment and participation in paid labour (Munger, 2002). Hence, notwithstanding cross-country variations, 
current social policies in the EU, US, Canada, UK, Israel and other Western countries (Fineman, 2004; Herbst and Benjamin, 2016; Jordan, 2018; Lightman et al., 2010; Nelson, 2011; Nieuwenhuis and Maldonado, 2018) are grounded in the notion that paid employment is the basis for all social rights of adults, regardless of class or gender (Lavee, 2016; Weigt, 2006). The reform in welfare services, with its retrenchment and increased deregulation and privatization, reflects this approach. Through the reduction of benefits, intensification of work requirements and imposition of time limits, welfare restructuring has aimed to promote personal responsibility and reinforce the notion of market citizenship (Gazso and McDaniel, 2010). Consequently, state support is limited in scope and no longer based on entitlement or the notion of social citizenship; rather, its goal is to promote people's attachment to the labour market (Galston, 2005).

One core element of welfare reforms is the focus on work activation and welfare-to-work programs (Nieuwenhuis and Maldonado, 2018). Accordingly, entitlement to state support is conditioned on individuals' work commitment and the effort and willingness they demonstrate to participate in the labour market (Munger, 2002; Achdut and Stier, 2020). The notion of market citizenship and selective and short-term state support has replaced the universal concept of social citizenship and the state's permanent commitment to the individual's wellbeing (Cox, 1998).

More than an ideological imperative, work commitment has a moral dimension, serving as an indication of character and a criterion for social inclusion or exclusion (Fineman, 2004). Those relying on official assistance and other forms of state support for survival are violating basic social norms and may be perceived as deviant and irresponsible (Feldman and Schram, 2019; Lavee and Strier, 2018). Schram and colleagues (2010) refer to this core moral imperative as part of the disciplinary project, in the context of poverty governance. This project, via various forms of governing mentalities (Campbell, 2002), aims to instill market values (Schram, 2008) and produce a self-disciplined individual. According to this reasoning, taking responsibility through labour market participation indicates one's appropriate morality, while being defined as the 'welfare poor' exposes one's shameful status. Welfare programs are constructed to provide the poor with an experience of market incentives and logic and to teach worker self-discipline. In such an environment,

Welfare clients' identities are defined by their state of passage from the degraded role of 'dependent' to the valorized role of 'worker' .... As such, they represent a kind of semicitizen in transition, subject to the enforcement of obligations yet not possessing the full rights of entitled membership (Schram et al., 2010: 745).

Literature focusing on the link between citizenship and exclusion demonstrates that, under a neoliberal disciplinary regime, it is not poverty itself that 
leads to exclusion, but rather welfare dependency and its implicit lack of personal responsibility and inability to achieve economic independence (Lavee, 2017; Offer, 2010). Consequently, excluded citizenship results in disentitlement to state support. However, if adhering to current definitions of who is an entitled citizen constructs perception of entitlement, it is possible that disciplining oneself in accordance with definitions of market citizenship could affect perceptions of inclusion and entitlement despite one's actual position as welfare reliant.

This study joins contemporary works that aim to explore how those on the bottom experience and respond to changing policy processes. We claim that understanding poor people's reaction to specific programs and policies (such as asset-building, work activation, social investment, etc.) is insufficient. A thorough comprehension of the overall reaction of the target population of these programs would enable a more nuanced analysis of their perceptions regarding entitlement to social rights. Such analysis would allow an understanding of the influence of structural forces on individuals' self-perceptions as included or excluded. These perceptions are crucial for deciphering how welfare recipients cope with the inherent excluding position embedded in their dependency. This study is important not only for exposing welfare recipients' personal feelings of inclusion or exclusion, but for examining their overall ability to resist exclusion and struggle to escape poverty.

\section{The Israeli case}

Israeli society constitutes a particularly instructive case for studying perceptions of entitlement to social rights under continuing welfare restructure, increasing poverty and inequality rates, together with relative generosity in specific welfare programs (Achdut and Stier, 2020). Originally, Israel was established as a social democratic welfare state and for years maintained a strong collectivist ethos (Doron, 2003). Since the late 1980s, however, it has gradually adopted a neoliberal welfare ideology, similar to other Western countries (Ajzenstadt, 2009).

Two major institutional changes occurred during the 1990s and 2000s: welfare state retrenchment and labor market decentralization (Levanon and Saburov, 2018). Over the last three decades, spending on social services as a percentage of GDP declined by $34 \%$ (Azari-Visal and Kogen, 2014). These changes intensified after the 2003 welfare reform, which imposed serious retrenchment in social expenditures and welfare restructuring (Maman and Rosenhek, 2011). Once-generous child benefits were drastically limited and stricter eligibility criteria for income maintenance benefits were enforced (Stier, 2011). Unemployment benefits became more limited and difficult to obtain; welfare allowances were severely cut; new eligibility requirements were imposed; and welfare-to-work programs were implemented. The major goal of this reform was to reduce the number of people entitled to income support by pushing welfare recipients into the workforce. With these ideological 
and policy changes, employment has become the optimal condition for citizenship (Ajzenstadt, 2009).

The change in policy had gender ramifications. Previously Israel's welfare policy had been oriented toward supporting women in their dual roles as caregivers and breadwinners. The 2003 reform, targeted at single mothers, drastically decreased allocations and other social services, such that the welfare regime withdrew support from those who doubled as mothers and workers (Lavee, 2016).

At the same time, the Israeli welfare regime combined a neoliberal ethos with social policy institutions traditionally built on a social democratic ideology. An example is the income support benefits for single mothers. While mothers who receive this support are required to report regularly to the local employment service and accept any job offered to them, the policy does not set specific working-hour requirements and sanctions are imposed only on those refusing to work at all. Moreover, because there is no time limit on receiving benefits, it is common that single mothers combine work and welfare for long periods.

Although the contemporary socioeconomic order emphasizes individualism and personal responsibility, Israeli society maintains a collectivist character. Studies have demonstrated that, in general, the public favors an inclusive welfare state and a generous social policy (Cohen et al., 2011; Lavee et al., 2018). The combination of 'old' and 'new' welfare in Israel (Postan-Aizik and Strier, 2020) makes it an ideal case to study the factors that shape individuals' sense of entitlement.

\section{Methodology}

The study included 76 participants. The inclusion criteria were receiving some kind of public support at the time of the interview, and living in poverty.

The sample included an overrepresentation of women $(\mathrm{N}=70$, with only 6 men) and of Jews ( $\mathrm{N}=70$, with only 6 Arabs). Regarding ethnic origin, 42 were born in Israel, 25 immigrated from the former Soviet Union (FSU), 4 immigrated from Ethiopia and 2 were born in Arab countries. A third (25) of the participants were married, while the others were divorced, single or widowed; all had children. In terms of age group, 40 participants were 25-40 years old, 28 were 40-55 years old, and 8 were 55-70 years old. As to education, 39 had a full or partial high school education, 14 had a secondary education, and 15 held an academic degree. All interviewees reported participating in the labour market in varying degrees. The vast majority held low-skilled positions (e.g. cashiers, waitresses, salespeople in shops, cleaners). A few worked in professional jobs, such as nurses and accountants. Many were employed in part-time or temporary positions. Some said they were temporarily unemployed, but all reported they were actively searching for jobs. In fact, even participants who considered themselves "unemployed" described working in occasional jobs, mainly cleaning and childcare. 
Participants were recruited via various strategies, aiming to ensure that potential interviewees met the criteria for inclusion in the study. We asked social workers at welfare offices to send letters to clients they believed would be interested in participating. Some participants were recruited through nonprofit organizations that provide assistance to poor families and others via social media. Finally, we used the snowball method, asking interviewees to refer us to other members of their social networks who might fit the study criteria. As the majority of clients of welfare departments and NGOs are women, they were the majority of our interviewees. Also a higher proportion of women and Jews were willing to take part in the study.

During our initial contact with potential participants (usually by phone), we explained the nature and goal of the study, asked for consent, and, if they agreed, scheduled an interview. We conducted semi-structured in-depth interviews, mostly in the respondent's home, but some in public settings such as parks or coffee shops. Interviews lasted one to two hours. The interviews were designed to determine welfare recipients' perception of the state's responsibility towards them under contemporary welfare ideology and shifting social policy. All interviews were transcribed verbatim and identifying details were replaced with pseudonyms.

Transcripts were analyzed according to the grounded theory method (Charmaz, 2014; Strauss and Corbin, 1990). The first step of the analysis was open coding, by which statements were named, divided into segments and scrutinized for commonalities that could reflect categories or themes. Axial coding was then performed, and connections were made among the categories and subcategories. According to Strauss and Corbin (1990), this reflects the idea of clustering open codes around specific points of intersection. Finally, selective theoretical coding was conducted. At this stage, the categories and their interrelationships were combined to form a storyline that described the influential relationship between macro-level ideology and policy, and individual perceptions of entitlement.

\section{Findings}

The study examined welfare recipients' perceptions of state responsibility for people who struggle with economic hardship, which come to the fore in their entitlement to state support. Three types of entitlement perception were revealed: entitlement based on social citizenship, excluded citizenship and hybrid entitlement. After briefly describing the first two types, which were rare, we will focus on the most common, hybrid entitlement.

\section{Entitlement based on social citizenship}

A small number of interviewees expressed perceptions of entitlement based on social citizenship. Such a sense of entitlement is a remnant of the welfare state 
in the sense that it builds upon perceptions of a generous universalist welfare state that is obligated to provide a wide range of social rights to its citizens. These perceptions were manifested in remarks such as: 'They need to reduce taxes, reduce costs of water, electricity, property tax. The situation is really difficult, so many people live in poverty, someone needs to care for them' (interview 1). 'They need to help me make ends meet, to live independently with my kids, and to raise income support, so I can feel that I live like all other people' (interview 49).

Not surprisingly, expectations of state support were salient in the accounts of participants aged 40 and above, who had witnessed the state's past ability to provide a wide safety net to its poor citizens and who perceived the state as responsible for their welfare and wellbeing: 'Bring back what was before, increase child support' (interview 2); 'I used to be able to get public housing; this needs to be true today as well' (interview 75).

\section{Excluded citizenship}

Very few participants perceived the state as not taking any responsibility: 'I think the state gives nothing to its citizens' (interview 29). Those who felt excluded also perceived themselves as disentitled to any social rights: 'I really don't want anything from the state, just to be left alone' (interview 31).

Perceptions of excluded citizenship and disentitlement were usually expressed by those who suffered the most severe economic hardship. One example was a 63-year-old immigrant from the former Soviet Union with an engineering degree, who had worked for the last few decades as a cleaner in Israel:

It's really disgusting that people have to work after retirement. I don't get anything from the government, and I've worked in this country for 45 years. Now I gave my body an order that it can't get sick; otherwise I have no money. I have to live like this, and they [the state] give money to new immigrants (interview 58).

Such feelings of exclusion were also expressed through anger and an active disconnection from state institutions, due to the perception that the state shirks responsibility for their social rights. This stance was demonstrated in the words of a single mother who described in detail, throughout the interview, her daily struggle to provide her children with the most basic needs:

Nothing makes sense in this country, it's like a banana republic! I don't even go to the welfare office. Instead of helping those in real need, they give money to families who earn 17,000 shekels! [about twice the minimum wage] (interview 47).

Lister (2004) and others (e.g. Lavee, 2017) point to negative feelings resulting from exclusion, such as shame and disrespect, which lead to active disconnection from institutions. Circumstances of this kind, when citizens feel abandoned, may even generate a willingness to leave the country: 'I don't get 
anything and don't want anything from the state. The only thing I want is to leave the state' (interview 66).

\section{Hybrid entitlement}

Alongside these relatively infrequent perceptions of entitlement, the analysis revealed a third type. The vast majority of interviewees (mostly women, especially mothers), who lived in poverty and received various kinds of welfare support, adjusted their entitlement perceptions to the neoliberal disciplining regime. They perceived labour market participation and independent breadwinning as supreme values. However, the analysis also revealed variations in selfdisciplining related to perceptions of state commitment to its citizens. Under the contemporary welfare environment in Israel, which combines 'new' values of market citizenship with 'old' ethics of state responsibility and social citizenship (Postan-Aizik and Strier, 2020), the latter permeate the former, creating a hybrid perception of entitlement.

The dictionary definition of "hybrid" is something having two kinds of components or combining two elements. We draw on this definition to frame the pattern that distinctly emerged from the data: a perception of entitlement composed of mixed parts. This perception was built upon the following rationale: as a moral citizen, I am not supposed to depend on state support but should participate in the labour market and provide for my family independently; nevertheless, the state is responsible for seeing to it that I am able to respond to this demand. If the state's objective is to create non-dependent citizens, it should take responsibility for providing me with the means to achieve this goal. The inductive data analysis pointed to three variations of hybrid entitlement described below.

\section{Entitlement to economic independence}

The ultimate value of market citizenship is implemented through welfare-towork programs, which are based on the rationale that people who work can succeed as self-sufficient citizens (Achdut and Stier, 2020; Morgen et al., 2013). However, ample research demonstrates that, in most cases, former welfare recipients are employed in jobs at the 'bottom' of the labour market, earn minimum wage and are far from self-sufficient (Collins and Mayer, 2010; Schram et al., 2010). Our Israeli participants acknowledged that they should participate in the labour market and be able to provide for their families independently through their wages. However, as in other countries, the jobs available to them did not allow them to be financially independent. Under these circumstances, they held the state responsible for providing the appropriate conditions for them to earn a sufficient livelihood via the labour market. They expressed this by maintaining that the state should set a minimum wage that could facilitate their economic independence: 'Raise the minimum wage' (interview 26); 'Higher 
salary. Minimum wage in the country should be at least commensurate with a person's expenses. It's inconceivable that life is so expensive, and salaries are all gone with nothing left until the next paycheck' (interview 22).

Most of the interviewees were engaged in manual labor: working as cleaners, cashiers and the like. They linked their physical exhaustion to insufficient salaries, as manifested in the next quote:

My salary is very small, I work very hard, I go home broken, my whole body hurts and then I have to start everything at home as well. I need to earn more, I feel frustrated. I wish the state would acknowledge that, all these demands, and raise salaries (interview 74).

The interviewees' perceptions of entitlement were not guided by previous understandings of the welfare state as a substitute for labour market income. They were well aware of contemporary moral standards of labour market participation. However, they maintained that the state should provide the required conditions to attain these moral standards: 'I'm not asking anyone for charity, I can achieve this myself, but I do ask to be given a way to move forward. My salary must be more than what I can get now, give us hope for a better economic future' (interview 64).

\section{Entitlement to labour market decommodification}

While labour market decommodification may seem an oxymoron, the analysis demonstrated that participants resisted becoming commodities. However, they did not frame their resistance through what is traditionally considered decommodification - entitlement to social rights and state protection when one cannot participate in the labour market (Esping-Andersen, 1990). Rather, they perceived the state as responsible for providing them with opportunities for employment, and a chance for self-fulfilment and job satisfaction. One participant explained:

Today there are state plans that return people to work, and there is a goal to be employed, but [the plans] need to be further refined, further improved. For example, people should be offered options for training, schooling, something that will really build them, that will give them usable tools in their hands. Give them opportunities to enter in a respectable manner into the labor market (interview 28).

Another participant, with a higher level of education and unable to find employment in her profession, stated:

Of course, I would say that minimum wage should be raised, but more opportunities should also be created. By profession, I'm an engineer, and I can't find work in my field. So I have to work in a low-paying shop. The state needs to allow people to work in a respectable manner (interview 21). 
The interviewees, welfare recipients, used market rationalities to explain their entitlement to state support; they refused to be considered commodities not in resistance to the labour market, but in order to become more productive citizens:

To the Prime Minister I would say that he should change the rules, how to motivate women like me to go to work. Because, honestly, if I were to work in an office with a head like mine, that I have, I have an open mind and I'm a quick learner, I believe that if I were to go work in a large office and with good work, I would give all I have. Truthfully, I believe I would not remain just a lowly clerk. I believe they would really see my abilities and my work and what I can really give of myself and I would move up. But as long as I'm stuck [in this job], I can't grow (interview 12).

Another respondent connected the value of individualism to market logic to explain her sense of entitlement to decommodification:

I would suggest to the state that, in order to encourage people to work, they should work in something that speaks to their heart. For instance, if I love to write and have no work in writing, the state can hire people to do what they love and pay them a stipend. To gain experience. Find creative solutions. Not only centers of employment placement, but centers of personalization, which will determine what kind of work is suitable for each person. Adjust the work to the people; people need a connection. Nowadays people who do not have work are usually sent to cleaning jobs, which they hate, and then they leave them (interview 5).

The above demonstrates how the neoliberal disciplining project and traditional expectations from the welfare state simultaneously influenced the selfperceptions of participants and their sense of entitlement. The interviewees embraced the neoliberal demand to fulfil their role as good citizens through devotion to the labour market. However, in return, they demanded the state demonstrate devotion to its citizens by promoting labour market conditions in which they could feel they were respected and included as members of society.

\section{Single mothers' entitlement to state support}

Welfare state support of single mothers is traditionally examined in terms of the extent to which the state encourages them to be committed to their maternal role and acknowledges them as primary caregivers of their children. Such support is manifested in the allowances and social services provided by the state, which permit single mothers to remain outside the labour market yet have sufficient income. Under the disciplinary regime of market citizenship, however, perceptions of single mothers' entitlement to support have changed. Our analysis demonstrated that single mothers perceived themselves as entitled to receive support in ways that allowed them to be committed to their worker rather than their maternal role: 'Undoubtedly, the state has to take care 
of mothers. It is not set up well at all. A mother who has children and wants to work, wants to earn a living, has no benefits' (interview 20).

Single mothers who are welfare-reliant are often stigmatized and condemned due to their dependency (Dodson, 2007; Feldman and Schram, 2019) and considered undeserving of collective support (Lavee and Benjamin, 2017). However, the following interviewee explained why single mothers are more independent than married mothers. Using the logic of responsibility, she rationalized her entitlement to state support:

Raise wages more, especially for a single parent. We are independent, not like married women who have a spouse to rely on. For example, if they give me the conditions to make ends meet, I would not rely on the National Insurance Institute for my entire life (interview 2).

Not all the participants remembered the 1990s when state support for single mothers was broad and generous, allowing them to care for their children while the state provided the necessary material resources. The younger interviewees had not even been born yet, but still were influenced by perceptions of a state that is responsible for single mothers. All the single mothers in the study maintained that the state should be responsible for them by supporting their market citizenship:

The state could do a lot if they wanted to. It could take care of the economic situation of single mothers. Most of us did not choose to be single parents, this is a situation we found ourselves in. The goal is to encourage working. There has to be some sort of strategy, the state should be responsible for a recovery plan for divorced women, so they can earn even more than other people, not like now; even though I work myself to death, my kids are still in poverty. Because after all, moving from the budget of two spouses to the finances of one spouse ... there should be help finding additional sources of employment to make sure that single mothers who work full-time like me can live in dignity (interview 15).

Another interviewee linked traditional expectations that a 'democratic and enlightened state' will provide social rights to its citizens to her ability to respond to the contemporary expectation of self-sufficiency:

I did not ask for a villa in the suburbs, I didn't even ask for a car. I asked for something basic! A normal salary so that I can work in only one job, be independent, so that I can continue to be a good mother to my children without having to worry about where I go for loans and get deeper and deeper into debt. I don't want this, it's oppressive! Yes, there are nights I don't sleep, as much as I try to tell myself that it's OK. And it should not be [that way]. Certainly not in a democratic and enlightened state such as ours (interview 62).

\section{Discussion}

In many Western countries, current welfare policy is based on a disciplinary regime that transforms the universalist notion of social citizenship into the 
neoliberal idea of market citizenship (Schram et al., 2010). This study's goal was to explain the factors that shape welfare-reliant individuals' perceptions of entitlement under the contemporary welfare environment. The inductive data analysis portrayed a process in which perceptions of entitlement to social rights were disciplined by the 'new' welfare regime of market citizenship, but simultaneously influenced by 'old' perceptions of universal citizenship rights. Alongside only a few perceptions of broad state responsibility and eligibility to a wide range of social rights, and even fewer perceptions of excluded citizenship - disentitlement to any kind of collective support - the data shows that the most common perceptions of entitlement drew on a combination of contemporary market citizenship values and traditional ethics of state responsibility. This hybrid entitlement directed the individual's sense of deserving public support. Although all participants were welfare recipients in times when dependence is condemned and stigmatized (Feldman and Schram, 2019; Fineman, 2004), their status as dependents and poor did not result in perceptions of excluded citizenship (Lister, 2004) or disentitlement (Benjamin, 2016). Instead, they viewed the state as obligated to provide them with the required support for economic survival. Moreover, although participants embraced the neoliberal imperative of labour market devotion as a sign of good citizenship, the analysis revealed no trend of entitlement based solely on market citizenship.

Our findings add another layer to the literature examining the negotiations made by those who receive collective support, and the moral considerations they adopt to cope with changing entitlement in the face of welfare reform (e.g. Grootegoed and Van Dijk, 2012; Weigt, 2006). The concept of hybrid citizenship points to a variation in individuals' sense of entitlement that diverges from the original purpose of the neoliberal disciplinary regime. It provides a broader perspective on the 'self-disciplined' individual, who does not passively adhere to the supreme value of market citizenship and perceive labour market participation as the sole definition of moral citizenship. Instead, hybrid perceptions of entitlement portray active negotiations by those receiving collective support, presenting them as agents who take advantage of ideological values to justify themselves as moral citizens.

As the vast majority of research participants were women, this study contributes to existing literature which emphasizes the urgency of focusing attention on the perspective of poor women, and to exploring how they experience and respond to macro-level processes (Feldman and Schram, 2019). Drawing on this stance, the emerging perceptions of hybrid entitlement may have particular gender ramifications. The voices of these women reinforce scholarly arguments concerning the centrality of social policy in facilitating poor women's ability to fulfil their dual roles as caregivers and independent breadwinners. As suggested by Orloff (2006), governments need to adopt strategies to reduce poverty and economic vulnerability by enhancing women's employment while ensuring that 
caregiving activities are supported. Such policy adjustment could draw on entitlement perceptions in order to better satisfy the needs of mothers living in poverty and providing for their families.

Can we understand the divergence of entitlement perceptions as genuine resistance to market rules and an alternative to the governing mentalities (Campbell, 2002) that structure the guiding rationale of contemporary social policy? Indeed, the data presents more inclusive perceptions of citizenship, based to a greater extent on reciprocal understanding of relations between the state and its citizens than upon the sole definition of personal responsibility. In other words, in the contemporary welfare environment, individuals assume that the state should provide them with the appropriate conditions for achieving the goal of personal responsibility.

Such negotiations over entitlement are far from signifying social change and do not contradict 'acceptance of the verdict of the marketplace' (Mead, 1986: $87)$. Instead, such perceptions more closely resemble the shift that Gilbert (2009) identifies in the policy goals of social entitlement advocates. Gilbert argues that, under a changing social contract between the state and its citizens, and as the social obligation to work has intensified, advocates of social entitlements are shifting the emphasis on policy reforms from responsibility to work to the social rights of low-income workers to earn a living wage. Facing the supreme value of the market, these advocates acknowledge that the right to a living wage attracts a broader spectrum of political support than a guarantee of cash assistance for the unemployed. It is easier to mobilize public support for government intervention that helps people who work hard and play by the rules to provide their families with a decent standard of living, than for programs that pay poor people to stay at home and care for their children. The same rationality is used by welfare recipients to justify deserving social inclusion and entitlement to state support. They do not base their eligibility for state support on definitions of social citizenship or on resistance to the neoliberal regime; rather, they leverage the discourse of market citizenship to justify their morality as dependents.

Like all studies, ours has limitations. First, there was a large overrepresentation of women among the participants. As such, it raises questions regarding the similarities and differences of perceptions of entitlement between genders. However, researchers have shown that "in the citizenship of a neoliberal era ... civic responsibilities are collapsed into the obligation to work and applied to poor women as much as to men" (Schram et al., 2010: 743) and that welfare reform is gender neutral in that it demands all able-bodied adults to demonstrate economic independence (Collins and Mayer, 2010; Munger, 2002). Assuming this to be the case, a more equal gender representation among the research sample is likely to yield similar patterns. 
Second, the case presented here is specific to time and place and to the nature of the welfare state. To further understand the implications of ideology and policy change on individuals' perceptions of citizenship and entitlement, as well as different forms this may take, additional research is required. Such research should highlight similarities and differences in various countries in the context of the processes described here. Exploring these possible variations will contribute to our understanding of various manifestations of the disciplining system and its relation to inclusion and exclusion definitions.

\section{Conflict of Interest}

The author declares none.

\section{Notes}

1 While Schram, among others, understands the concept of "market citizenship" as a neoliberal idea, there are those who do not. This concept may not be distinctly neoliberal and is rooted in the discussion between Titmuss and other welfare state scholars. Titmuss and his allies do not defend a purely universal welfare model, but favour a mixture of universal and selective services and benefits. Their approach differs significantly from Hayek, Friedman and their popularizers, who argue that state-provided services should be handled by the private sector on normal market principles, except for very hard cases needing direct state intervention. For more details, see Fontaine (2002).

2 The discussion of exclusionary mechanisms regarding citizenship is broad and applied in many research areas (e.g. politics, immigration studies). Here we refer to exclusionary mechanisms based on class.

\section{References}

Achdut, N. and Stier, H. (2020), 'Welfare-use Accumulation and Chronic Dependency in Israel: The Role of Structural Factors', Journal of Social Policy, 49,1, 81-101.

Ajzenstadt, M. (2009), 'Moral panic and neoliberalism: the case of single mothers on welfare in Israel', British Journal of Criminology, 49, 1, 68-87.

Arnot, M. and Dillabough, J.A. (eds.) (2000), Challenging Democracy: International Perspectives on Gender, Education and Citizenship, New York: Routledge.

Azari-Visal, S. and Kogen, J. (2014), 'Social spending figures,' in D. Ben-David (ed.), The State of the Nation Report, Jerusalem: Taub Center, 265-84 [Hebrew].

Benjamin, O. (2016), Gendering Israel's Outsourcing: The Erasure of Employees' Caring Skills, UK: Springer.

Campbell, N. (2002), Using Women: Gender, Drug Policy, and Social Justice, New York: Routledge.

Charmaz, K. (2014), Constructing Grounded Theory, London: Sage.

Cohen, N., Mizrahi, S. and Yuval, F. (2011), 'Public attitudes towards the welfare state and public policy: the Israeli experience', Israel Affairs, 17, 4, 621-43.

Collins, J. L. and Mayer, V. (2010), Both Hands Tied: Welfare Reform and the Race to the Bottom in the Low-wage Labor Market, Chicago: University of Chicago Press.

Cox, R. H. (1998), 'The consequences of welfare reform: how conceptions of social rights are changing', Journal of Social Policy, 27, 1, 1-16. 
Crenson, M. A. and Ginsberg, B. (2004), Downsizing Democracy: How America Sidelined its Citizens and Privatized its Public, Baltimore: Johns Hopkins University Press.

Dean, M. (2010), Governmentality: Power and Rule in Modern Society, London: Sage.

Dodson, L. (2007), 'Wage-poor mothers and moral economy', Social Politics, 14, 2, 258-80.

Doron, A. (2003), 'The Israeli welfare regime: changing trends and their societal effects', Israeli Sociology, 5, 2, 417-34 [Hebrew].

Esping-Andersen, G. (1990), The Three Worlds of Welfare Capitalism, London: Polity.

Feldman, G. and Schram, S. F. (2019), 'Entrepreneurs of Themselves: How Poor Women Enact Asset-Building Discourse', Journal of Social Policy, 48, 4, 651-669.

Fineman, M. (2004), The Autonomy Myth: A Theory of Dependency, New York: The New Press.

Fontaine, P. (2002), 'Blood, politics, and social science: Richard Titmuss and the Institute of Economic Affairs, 1957-1973', Isis, 93, 3, 401-34.

Galston, W. (2005), 'Conditional citizenship', in L. M. Mead and C. Beam (eds.), Welfare Reform and Political Theory, New York: Russell Sage Foundation, 110-26.

Gazso, A. and McDaniel, S.A. (2010), 'The risks of being a lone mother on income support in Canada and the USA', International Journal of Sociology and Social Policy, 30, 7/8, 368-86.

Gilbert, N. (2009), 'US welfare reform: rewriting the social contract', Journal of Social Policy, $38,3,383-99$.

Grootegoed, E. and Van Dijk, D. (2012), 'The return of the family? Welfare state retrenchment and client autonomy in long-term care', Journal of Social Policy, 41, 4, 677-94.

Hacker, J. S. (2019), The Great Risk Shift: The New Economic Insecurity and the Decline of the American Dream, Oxford: Oxford University Press.

Harvey, D. (2007), A Brief History of Neoliberalism, New York: Oxford University Press.

Herbst, A. and Benjamin, O. (2016), 'Between activation and supporting women: Alternative operation of welfare-to-work programmes', Social Policy \& Administration, 50, 5, 501-19.

Jordan, J. D. (2018), 'Welfare grunters and workfare monsters? An empirical review of the operation of two UK "work programme" centres', Journal of Social Policy, 47, 3, 583-601.

Krumer-Nevo, M. (2002), 'The arena of othering: a life-story study with women living in poverty and social marginality', Qualitative Social Work, 1, 3, 303-18.

Lavee, E. (2016), 'The neoliberal mom: How a discursive coalition shapes low-income mothers' labor market participation', Community, Work \& Family, 19, 4, 501-518.

Lavee, E. (2017), 'Low-income women's encounters with social services: Negotiation over power, knowledge and respectability', British Journal of Social Work, 47, 5, 1554-1571.

Lavee, E. and Benjamin, O. (2017), 'Between social rights and human rights: Israeli mothers' right to be protected from poverty and prostitution', Journal of comparative family studies, 48, 3, 315-326.

Lavee, E. and Strier, R. (2018), 'Social workers' emotional labour with families in poverty: Neoliberal fatigue?', Child \& Family Social Work, 23, 3, 504-512.

Lavee, E., Cohen, N. and Nouman, H. (2018), 'Reinforcing public responsibility? Influences and practices in street-level bureaucrats' engagement in policy design', Public Administration, 96, 2, 333-348.

Levanon, A. and Saburov, E. (2018), 'Changes in the demographic antecedents of poverty among workers in Israel, 1991-2011', in H. Lohmann and I. Marx (eds.), Handbook on In-Work Poverty, Cheltenham, UK: Elgar, 434-48.

Liebenberg, L., Ungar, M. and Ikeda, J. (2015), 'Neo-liberalism and responsibilisation in the discourse of social service workers', British Journal of Social Work, 45, 3, 1006-21.

Lightman, E., Mitchell, A. and Herd, D. (2010), 'Cycling off and on welfare in Canada', Journal of Social Policy, 39, 4, 523-42.

Lister, R. (2004), Poverty, Cambridge, UK: Polity.

Lister, R. (2008), 'Inclusive citizenship, gender and poverty: some implications for education for citizenship', Citizenship Teaching and Learning, 4, 1, 3-19.

Maman, D. and Rosenhek, Z. (2011), The Israeli Central Bank: Political Economy, Global Logics and Local Actors, New York: Routledge. 
Marshall, T. H. (1950), Citizenship and Social Class: And Other Essays, Cambridge, UK: Cambridge University Press.

Mead, L. M. (1986), Beyond Entitlement: The Social Obligations of Citizenship, New York: The Free Press.

Morgen, S. L., Acker, J. and Weigt, J. (2013), Stretched Thin: Poor Families, Welfare Work, and Welfare Reform, New York: Cornell University Press.

Munger, F. (ed.) (2002), Laboring Below the Line: The New Ethnography of Poverty, Low-wage Work, and Survival in the Global Economy, New York: Russell Sage Foundation.

Nelson, K. (2011), 'Social assistance and EU poverty thresholds 1990-2008: Are European welfare systems providing just and fair protection against low income?, European Sociological Review, 29, 2, 386-401.

Nieuwenhuis, R. and Maldonado, L.C. (2018), The Triple Bind of Single-Parent Families, Bristol: Policy Press.

Offer, S. (2010), 'Agency-based support: a "last-resort" strategy for low-income families?', Social Science Quarterly, 91, 1, 284-300.

Orloff, A.S. (2006), 'Farewell to maternalism? State policies and mothers' employment', in J.D. Levy (ed.), The State After Statism, Cambridge, MA: Harvard University Press, 230-68.

Postan-Aizik, D. and Strier, R. (2020), 'From Social Investment to Investing in the Social: Insiders' Perceptions, Experiences, and Expectations', Journal of Social Policy, 1-18.

Pinson, H. (2008), 'The excluded citizenship identity: Palestinian/Arab Israeli young people negotiating their political identities', British Journal of Sociology of Education, 29, 2, 201-12.

Schram, S.F. (2008), Welfare Discipline: Discourse, Governance, and Globalization, Philadelphia, PA: Temple University Press.

Schram, S.F., Soss, J., Houser, L. and Fording, R.C. (2010), 'The third level of US welfare reform: governmentality under neoliberal paternalism', Citizenship Studies, 14, 6, 739-54.

Soss, J., Fording, R. and Schram, S.F. (2011), 'The organization of discipline: from performance management to perversity and punishment', Journal of Public Administration Research and Theory, 21, 2, i203-32.

Stier, H. (2011), 'Working and poor', in D. Ben-David (ed.), State of the Nation Report, Jerusalem: Taub Center, 153-203 [Hebrew].

Strauss, A. and Corbin, J. (1990), Basics of Qualitative Research, New York: Sage.

Strier, R. (2005), 'Gendered realities of poverty: men and women's views of poverty in Jerusalem', Social Service Review, 79, 2, 344-67.

Weigt, J. (2006), 'Compromises to carework: the social organization of mothers' experiences in the low-wage labor market after welfare reform', Social Problems, 53, 3, 332-51. 